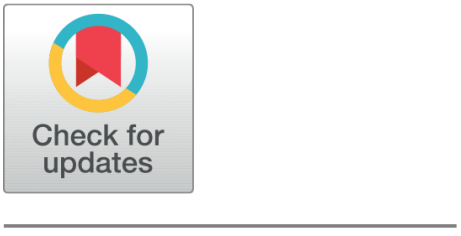

OPEN ACCESS

Received: 23.01.2021

Accepted: 24.02.2021

Published: 04.03 .2021

Citation: Mumtaz Y, Nasiri A, Tetsuhiro S (2021) A comparative study on retrofitting concrete column by FRP-Wrapping and RC-Jacketing methods: A feasibility study for Afghanistan. Indian Journal of Science and Technology 14(7): 652-664. https://doi.org/ 10.17485/IJST/v14i7.141

Corresponding author.

Tel: +81-8081269017 yasin.mumtaz.malik@gmail.com, k208487@eve.u-ryukyu.ac.jp

Funding: University of the Ryukyus

Competing Interests: None

Copyright: (c) 2021 Mumtaz et al. This is an open access article distributed under the terms of the Creative Commons Attribution License, which permits unrestricted use, distribution, and reproduction in any medium, provided the original author and source are credited.

Published By Indian Society for Education and Environment (iSee)

ISSN

Print: 0974-6846

Electronic: 0974-5645

\section{A comparative study on retrofitting concrete column by FRP-Wrapping and RC-Jacketing methods: A feasibility study for Afghanistan}

\author{
Yasin Mumtaz ${ }^{1 *}$, Ahmadullah Nasiri ${ }^{1}$, Shimozato Tetsuhiro ${ }^{2}$ \\ 1 Department of Civil Engineering and Architecture, Graduate School of Engineering and \\ Science, University of the Ryukyus, 903-0129, Okinawa, Japan. Tel.: +81-8081269017 \\ 2 Professor, Department of Civil Engineering and Architecture, Graduate School of \\ Engineering and Science, University of the Ryukyus, 903-0129, Okinawa, Japan
}

\section{Abstract}

Background/Objectives: FRP (Fiber Reinforced Polymer) has a wide range of application areas within the construction industry and is used in various forms and shapes, primarily for maintenance purposes. Using FRP has numerous advantages and disadvantages driven by several factors, including the country where it is used. The present paper focuses on the feasibility of using FRP in Afghanistan, considering load carrying capacity, cost, time efficiency, and environmental concerns as the main parameters. Method: In this numerical study, RC-jacketing and FRP-wrapping methods were evaluated for strengthening/repairing RC columns, and a comparison of the two methods was carried out to understand which approach better meets the maintenance needs in Afghanistan. Findings: As a result, the RC-jacketing method was more efficient in terms of cost and strength, while the FRPwrapping method proved its efficiency in terms of time and lower emission of $\mathrm{CO}_{2}$. Moreover, the RC-jacketing method was found to be more suitable and aligned with the country's current architecture. Overall, as the cost is the leading parameter in a developing country like Afghanistan, RC-jacketing was more suitable for conducting the maintenance work. Additionally, the authors also recommended using the FRP-wrapping method in some particular circumstances where the RC-jacketing method was believed to be less efficient.

Keywords: RC-Jacketing; FRP-Wrapping; retrofitting; reinforced concrete columns; strength; cost-effectiveness

\section{Introduction}

Most of the structures in Afghanistan are weak and vulnerable to collapse because of the continuous war that lasted almost three decades ${ }^{(1)}$. These structures were bombed and subjected to different kinds of dynamic loads, which are still going on. Another reasons are; use of unstandardized and low-quality construction material, equipment, practices, overloading, aging, and corrosion, which significantly weakens even new structures 
and requires maintenance ${ }^{(2-12)}$. Considering that building new structures in totality is costly and entirely out of Afghanistan's budget (and other third-world countries), a cost-effective strengthening method should be introduced. Recently, for the strengthening of the weak and deteriorated columns, fiber-reinforced polymer (FRP), which is a new maintenance material in Afghanistan, is being used and thought to be an ideal replacement for RC-jacketing.

FRP has caught the researchers' attention as a new strengthening material, and several studies have been conducted on its structural behavior and strength used as a maintenance material in the civil engineering field. FRP has been under study for few decades as a new strengthening method where it has proved its efficiency tremendously. Several studies have been conducted to scrutinize FRP's overall effectiveness, including strength and boundary conditions ${ }^{(13-17)}$ and ${ }^{(18)}$. FRP wrapping has promised improved ductility by averting brittle shear failure of columns ${ }^{(19,20)}$, increase in shear strength ${ }^{(21)}$, and can delay the damage in compression zone and buckling in longitudinal reinforcement ${ }^{(22)}$. Moreover, it prevents brittle shear failure ${ }^{(23)}$, and the nominal shear capacity of the column can also be attained ${ }^{(24)}$. Besides, it prevents the Poisson's effect by providing confinement pressure and keeping the RC column in its three-dimensional state. However, debonding is a major issue with FRP wrapping assessed so far ${ }^{(25)}$. Moreover, while using FRP wrapping, it was also noticed that displacement ductility and drift capacity do not increase beyond a specific limit ${ }^{(26)}$. Furthermore, the circular or elliptical wrapping (for circular or elliptical columns) is recommended because square or rectangular wrapping (for square or rectangular columns) cannot resist slipping (Figure 1$)^{(27,28)}$. Its brittle behavior, low resistance to heat, and lower ductility than steel is another demerit that should be considered while using this material. While FRP has been scrutinized as a strengthening material based on its structural characteristics, but some parameters directly affect the decision while choosing an efficient strengthening method for structures, which are often ignored by most of the studies, such as its total cost and time analysis, including environmental safety concerns (CO2 emission amount). On the other hand, RC-jacketing, which is one of the most frequently used techniques to strengthen reinforced concrete (RC) columns, has also been studied by several researchers for strengthening the weak structures to efficiently restore the loadcarrying capacity ${ }^{(29,30)}$. A statistical study conducted to investigate methods used for strengthening 114 concrete structures damaged by an earthquake in 1985 revealed that RC-Jacketing was widely used as the strengthening method ${ }^{(31)}$. Looking at RC jacketing's structural characteristics, this method can enhance both strength and ductility with stiffness ${ }^{(32)}$. In addition to increasing the target member's strength and ductility, it uniformly improves the structure's overall behavior. It was also proved that RC jacketing could change a strong beam weak column's condition into a strong column weak beam ${ }^{(33)}$. Furthermore, the RC-Jacketing method can enhance a damaged column's strength three times as the original one ${ }^{(34)}$. A similar study on RC frames showed a five times increase in lateral strength than the original frame ${ }^{(35)}$. However, the RC-Jacketing procedure is not sophisticated and needs much care during surface curing; else, the jacket can be separated ${ }^{(36)}$. On the other hand, RC jacketing can enhance a moderately damaged column's strength only and is useless for strengthening severely deteriorated columns ${ }^{(37)}$. Moreover, this method changes the column's cross-sectional area, adds to the members' brittleness, and decreases effective floor area, which also ends up in major architectural changes of the structure. Further, this method adds more load to an already weak structure, which puts rest members under extra load and leaves the whole structure vulnerable to further retrofitting. At the same time, it is more critical with high-rise structures. Drilling and providing holes for longitudinal reinforcement is also problematic in this method and can damage the structure if proper care is not taken ${ }^{(38)}$.
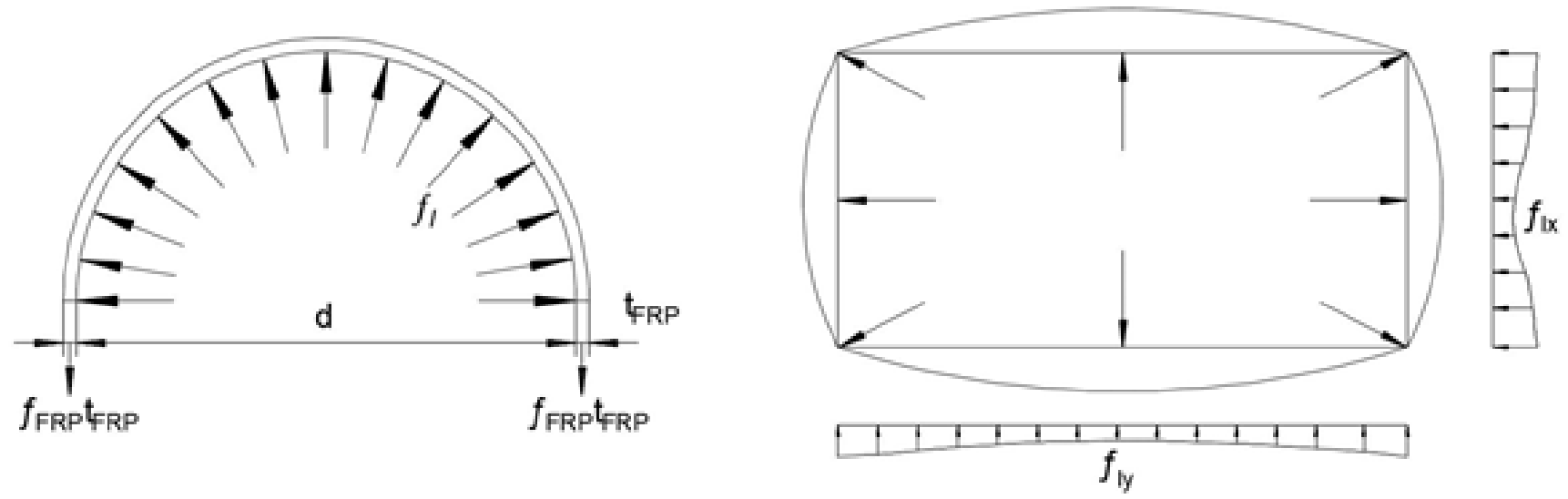

Fig 1. Confining pressure distribution of rectangular and circular cross-sections; $f 1$ - the confining pressure; $f$ FRP - FRP longitudinal tensile strength; $\mathrm{d}$ - the diameter of the RC column cross-section; tFRP - thickness of the composite material; $f$ lx, $\mathrm{y}$ - the confining pressures are given by $\mathrm{x}$ - and $\mathrm{y}$-directions. (Ciprian.C et al.) 


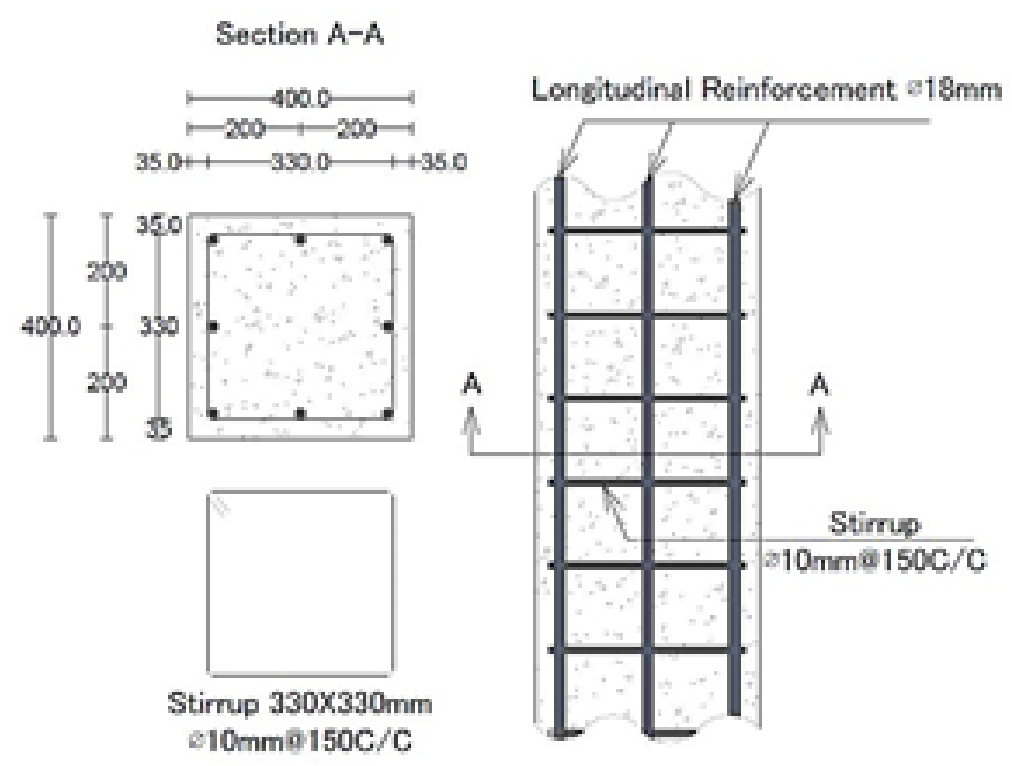

Fig 2. Geometry and reinforcement details of the original column

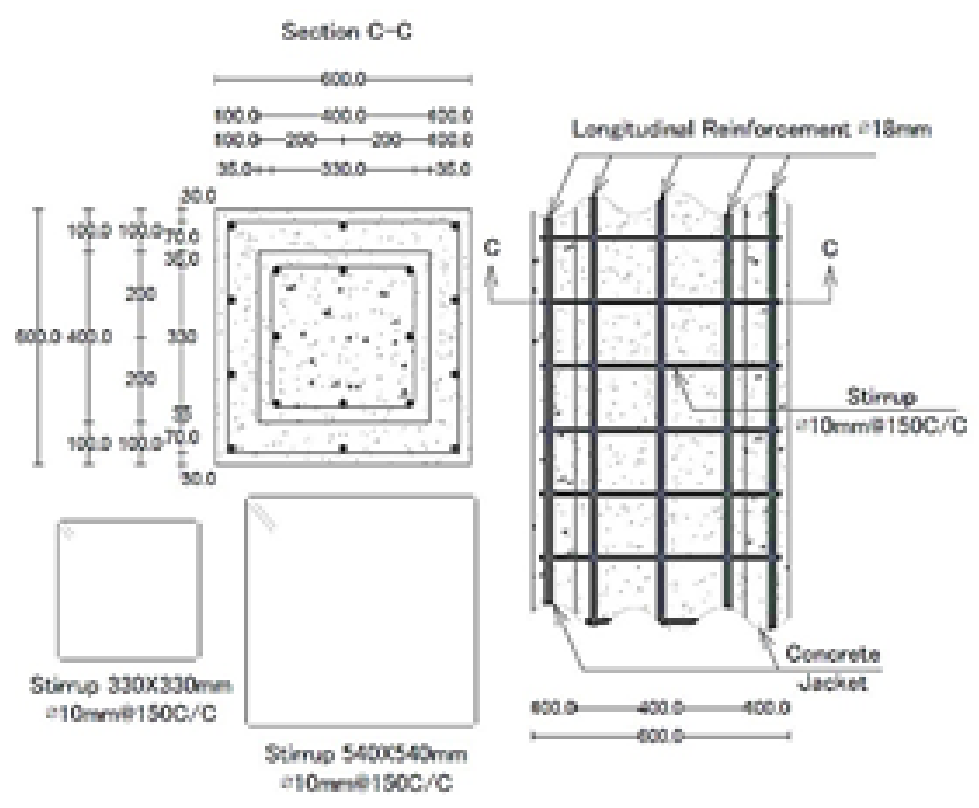

Fig 3. Geometry and reinforcement details of RC-jacketed column

Finally, several studies on the structural behavior of both FRP wrapping and RC-Jacketing have been conducted. Fewer studies have been presented to show their efficiency in cost, time, and environmental safety, which are major concerns in a country with limited resources like Afghanistan. Thus, this paper studied the feasibility of using the FRP-wrapping method as a strengthening/repairing material for concrete columns by comparing it to the RC-jacketing method by considering the mentioned parameters. The result of this numerical study showed that the FRP-wrapping method was more efficient in terms of time and environmental protection (less $\mathrm{CO}_{2}$ emission); however, the RC-jacketing method was more efficient in terms of strength (recovering load carrying capacity), cost, and better matching the architecture of the country. 


\section{Methodology}

The feasibility study of using FRP as a strengthening material for columns in Afghanistan is based on parameters such as its strength, cost, time, and environmental concerns (CO2 footprint). This study includes the following steps for evaluating the feasibility of using the FRP-Wrapping method in Afghanistan widely.

1. A typical column of $(450 \mathrm{~mm} \times 450 \mathrm{~mm} \times 3000 \mathrm{~mm})$ was considered for the study, which was projected to axial loading, and the load-carrying capacity was calculated for RC-jacketing and FRP wrapping methods before and after deterioration.

2. Architectural characteristic (geometry of structures in Kabul city was presented)

3. Cost analysis for both methods was presented.

4. Time analysis of both methods was presented.

\subsection{RC jacketing}

\subsubsection{RC jacketing}

Currently, the Indian code is utilized for calculations as Afghanistan codes are still under process. IS 456: 2000 section 39.3 proposes the following formula for calculating the column's load-carrying capacity/strength (Fiq. 2,3).

$$
\text { Pu }=0.4 \times \text { fck } \times \text { Ac }+0.67 \times \text { fy } \times \text { Asc }
$$

Where;

$$
\text { column }=400 \times 400 \times 3000 \mathrm{~mm}
$$

Load carrying capacity before deterioration.

$8 \phi 18 \mathrm{~mm} 156 \mathrm{c} / \mathrm{c}$ has been used

$$
P u=2283 K N
$$

Load carrying capacity after deterioration.

$f c k=18.2$ after $40 \%$ deterioration and around $60 \%$ of corrosion is calculated as bellow

$$
P u^{\prime}=1356.05 K N
$$

Load carrying capacity after jacketing.

$$
\mathrm{Pu}^{\prime}=0.4 \times \mathrm{fck} \times \mathrm{Ac}^{\prime}+0.67 \times \mathrm{fy} \times \mathrm{Asc}^{\prime}
$$

$A c^{\prime}=$ Jacketing concrete area

$A s c^{\prime}=$ Jacketing steel area

The area added as a jacket can also be calculated through the formula provided by ACI 318-08 as bellow

$$
A_{\text {g jacket }}=\frac{P_{u}}{0.6375\left(\left(0.85 f_{c}^{\prime}\right)+\rho\left(f_{y}-0.85 f_{c}^{\prime}\right)\right.}
$$

However, this paper has used the IS (Indian Standard) code as it is most often used in Afghanistan. Thus, according to IS 15988:2013, 8.5.1.2 C, the minimum jacketing provided on each side should be $100 \mathrm{~mm}$.

$$
=(600 \times 600)-(400 \times 400)=200000 \mathrm{~mm}^{2}
$$

For maximum condition is calculated

$$
\text { As Jacket }=\frac{4}{3} \text { As }_{\text {Concrete Original }}
$$

$10 \phi 18 \mathrm{~mm}$ have been used

$$
\text { RC Jacket Strenth }=2894.66 K N
$$




$$
\begin{gathered}
\text { Total Strength after jacketing }\left(P u^{\prime \prime}\right)=\text { Deteriorated strength }+ \text { Jacketing Strength } \\
P u^{\prime \prime} 1=\text { Original }+ \text { Jacketing Strength }=2283 K N+2894.66 K N=5177.66 K N \\
P u^{\prime \prime} 2=\text { Deteriorated }+ \text { Jacketing Strength }=1356.05 K N+2894.66 K N=4250.71 K N
\end{gathered}
$$

Strength increase in control column case

$$
\left(\frac{(5177.66-2283)}{2283}\right) \times 100=126.8 \%
$$

Strength increase in deteriorated column case

$$
\left(\frac{(4250.7-1356.05)}{1356.05}\right) \times 100=213.5 \%
$$

\subsubsection{FRP Wrapping}

Axial strength for the column can be calculated by equation (1.1) with the replacement of $f^{\prime} c c=f c k(1+\alpha p c \times \omega w)$. The calculations are conducted in accordance with IS 15988: 2013 guidelines. The calculations are for two layers of FRP (Figure 4).

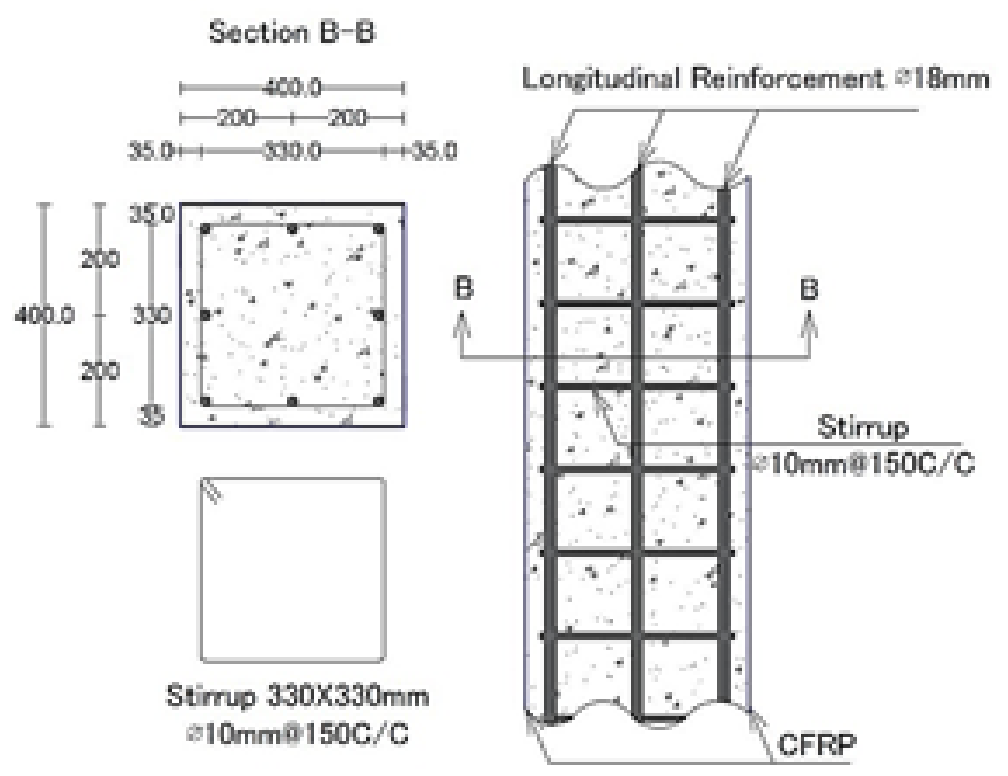

Fig 4. Geometry and reinforcement details of FRP-wrapped column

$$
\begin{gathered}
P u^{\prime}=0.4 \times f^{\prime} c c \times A c+0.67 \times f y \times A s c \\
f^{\prime} c c=f c k(1+\alpha p c \times \omega w)
\end{gathered}
$$




$$
P u=\phi c \times \alpha \times f^{\prime} c c(A g-A s t)+\phi s \times f y \times A s t
$$

The calculation for two layers of FRP where $\alpha$ is equal to 0.6

FRP Wrapped Original Column Strength $=4176.25 \mathrm{KN}$

FRP Wrapped Deteriorated Column Strength $=3082 \mathrm{KN}$

Strength increase in control column case

$$
\left(\frac{(4176.25-2283)}{2283}\right) \times 100=82.9 \%
$$

Strength increase in deteriorated column case

$$
\left(\frac{(3082-1356.05)}{1356.05}\right) \times 100=127 \%
$$

\subsection{Architectural characteristic (Geometry) of structures in Kabul city and overall Afghanistan}

Considering Afghan architecture, the survey data shows that almost $60 \%$ of residential buildings are two floored structures, while up to $65 \%$ of government buildings are three to five floors (Table 1). Moreover, around $90 \%$ have rectangular columns regardless of their occupancy type. Additionally, in Afghanistan, people tend to build a house and later decide to add more floors; this puts RC columns under tremendous pressure and causes failure. Almost $90 \%$ of residential buildings add more floors after the structure's construction, and around $60 \%$ of governmental buildings do so because of the lack of budget. Thus, taking all these calculations and unique construction facts into consideration, RC-jacketing can be more useful for strengthening low-rise buildings in Afghanistan because 90 to $95 \%$ of buildings rectangular column shape, which is inefficient because of their weak

\begin{tabular}{|c|c|c|c|c|c|c|c|c|}
\hline \multirow{2}{*}{ Type of occupancy } & \multicolumn{2}{|c|}{ Material type } & \multicolumn{3}{|c|}{ Floors } & \multirow{2}{*}{$\begin{array}{l}\text { Initially build } \\
\text { and later } \\
\text { added floors }\end{array}$} & \multicolumn{2}{|c|}{ Column cross-sectional shape } \\
\hline & $\begin{array}{l}\text { Brick } \\
\text { Masonry }\end{array}$ & Concrete & 1 & 2 & $3-5$ & & Rectangular & Circular \\
\hline Residential House & $30 \%-40 \%$ & $60 \%-70 \%$ & $30 \%$ & $60 \%$ & $10 \%$ & $90 \%$ & $95 \%$ & $5 \%$ \\
\hline $\begin{array}{l}\text { Governmental and } \\
\text { public facility }\end{array}$ & $10 \%$ & $90 \%$ & $5 \%$ & $30 \%$ & $65 \%$ & $60 \%$ & $90 \%$ & $10 \%$ \\
\hline
\end{tabular}
confinement adding several floors to the building after built is a prevalent practice in Afghanistan.

Table 1. Survey data from 190 residential, governmental buildings and facilities in Kabul City, Afghanistan

\subsection{Cost analysis}

A cost breakdown list was made for both methods, and local cost for each item/activity was assigned, where the unit was selected USD (United States of America) as a common practice and better understanding. The effort was made to create the breakdown list in such a manner that includes all activities/ items for both methods, and an average cost per item/ activity was used. The cost breakdown includes the cost for FRP (Table 2) and the fuel required (Table 3), as well as the cost for RC-Jacketing material (Table 4) and the fuel cost for it (Table 5). 
Table 2. Breakdown of activities for FRP wrapping method.

\begin{tabular}{llllll}
\hline NO & Descriptions & Unit & Quantity & Unit Cost (USD) & Total Cost (USD) \\
\hline 1 & $\begin{array}{l}\text { Mobilization and establishment of a } \\
\text { temporary camp for storing/keeping } \\
\text { equipment }\end{array}$ & LS (Labor Scale) & 1 & 150 & 150 \\
2 & Pre-Curing & $\mathrm{m} 2$ & 4.8 & 16.5 & 79.2 \\
3 & Adhesive (Primer, Polyurea, Resin) & Pack & $\mathrm{m} 2$ & 0.4 & 500 \\
4 & CFRP & LS (Labor Scale) & 15 & 20.8 & 300 \\
5 & $\begin{array}{l}\text { Extra costs such as delays and security } \\
\text { calculated for a minimum of 25 Km }\end{array}$ & LS (Labor Scale) & 1 & 183.5 & 100 \\
6 & $\begin{array}{l}\text { Demobilization and site cleaning } \\
7\end{array}$ & Total (USD) & & & 2034 \\
\hline
\end{tabular}

Table 3. Fuel required for providing uninterrupted electricity.

\begin{tabular}{|c|c|c|c|c|c|}
\hline $\mathrm{NO}$ & Descriptions & Unit & Quantity & Unit Cost (USD) & Total Cost (USD) \\
\hline 1 & $\begin{array}{l}\text { Mobilization and establishment of a temporary camp for } \\
\text { storing/keeping equipment }\end{array}$ & Liters & 5 & 0.604 & 3.02 \\
\hline 2 & Pre-Curing & Liters & 2.83 & 0.604 & 1.709 \\
\hline 3 & Adhesive (Primer, Polyurea, Resin) & Liters & 2.83 & 0.604 & 1.709 \\
\hline 4 & CFRP & Liters & 2.83 & 0.604 & 1.709 \\
\hline 5 & $\begin{array}{l}\text { Extra costs such as delays and security calculated for a } \\
\text { minimum of } 25 \mathrm{Km}\end{array}$ & Liters & 8.49 & 0.604 & 5.128 \\
\hline 6 & Demobilization and site cleaning & Liters & 5 & 0.604 & 3.02 \\
\hline 7 & Total (USD) & & & & 16.296 \\
\hline
\end{tabular}

Table 4. Breakdown of activities for RC jacketing method

\begin{tabular}{llllll}
\hline NO & Descriptions & Unit & Quantity & Unit Cost (USD) & Total Cost (USD) \\
\hline 1 & $\begin{array}{l}\text { Mobilization and establishment of a temporary } \\
\text { camp for storing/keeping equipment }\end{array}$ & LS (Labor Scale) & 1 & 180 & 180 \\
2 & Pre-Curing & $\mathrm{m} 2$ & 4.8 & 20 & 96 \\
3 & Concrete (with formwork and all required activities) & $\mathrm{m} 3$ & 0.48 & 130 & 62.4 \\
4 & Hilti Hit-hy 200 adhesive for steel anchorage & No & 1 & 160 & 160 \\
5 & Extra costs such as delays and security calculated for & LS (Labor Scale) & 1 & 1 & 250 \\
6 & $\begin{array}{l}\text { a minimum of 25 Km } \\
7\end{array}$ & Lemobilization and site cleaning & & & 100 \\
\end{tabular}

Table 5. Fuel required for providing uninterrupted electricity.

\begin{tabular}{|c|c|c|c|c|c|}
\hline NO & Descriptions & Unit & Quantity & Unit Cost (USD) & Total Cost (USD) \\
\hline 1 & $\begin{array}{l}\text { Mobilization and establishment of a temporary camp for } \\
\text { storing/keeping equipment }\end{array}$ & Liters & 10 & 0.604 & 6.04 \\
\hline 2 & Pre-Curing & Liters & 8.49 & 0.604 & 5.128 \\
\hline 3 & Concrete (with formwork and all required activities) & Liters & 14.15 & 0.604 & 8.547 \\
\hline 4 & Hilti Hit-hy 200 adhesive for steel anchorage & Liters & 2.83 & 0.604 & 1.709 \\
\hline 5 & $\begin{array}{l}\text { Extra costs such as delays and security calculated for a } \\
\text { minimum of } 25 \mathrm{Km}\end{array}$ & Liters & 14.15 & 0.604 & 8.547 \\
\hline 6 & Demobilization and site cleaning & Liters & 10 & 0.604 & 6.04 \\
\hline 7 & Total (USD) & & & & 36.01 \\
\hline
\end{tabular}




\subsection{Time analysis}

A time breakdown list was created under activities done for both FRP-Wrapping (Table 6) and RC-jacketing (Table 7) methods; minimum time was allocated for each activity per local labor demand.

Table 6. Time required for FRP wrapping method and hourly payment cost.

\begin{tabular}{|c|c|c|c|c|c|}
\hline $\mathrm{NO}$ & Descriptions & Unit & Quantity & Unit Cost (USD) & Total Cost (USD) \\
\hline 1 & $\begin{array}{l}\text { Mobilization and establishment of a temporary camp for } \\
\text { storing/keeping equipment }\end{array}$ & Hours & 3 & 0.796 & 2.388 \\
\hline 2 & Pre-Curing & Hours & 1 & 3.5 & 3.5 \\
\hline 3 & Adhesive (Primer, Polyurea, Resin) & Hours & 24 & 3.5 & 84 \\
\hline 4 & CFRP & Hours & 1 & 3.5 & 3.5 \\
\hline 5 & $\begin{array}{l}\text { Extra costs such as delays and security calculated for a } \\
\text { minimum of } 25 \mathrm{Km}\end{array}$ & Hours & 2.5 & 3.5 & 8.75 \\
\hline 6 & Demobilization and site cleaning & Hours & 2 & 0.796 & 1.592 \\
\hline 7 & Total Time Required (Hr) & 33.5 & & & \\
\hline 8 & Total Labor Payment (USD) & & & & 103.73 \\
\hline
\end{tabular}

Table 7. The time required for the RC-Jacketing method and amount of payment for labor

\begin{tabular}{|c|c|c|c|c|c|}
\hline NO & Descriptions & Unit & Quantity & Unit Cost (USD) & Total Cost (USD) \\
\hline 1 & $\begin{array}{l}\text { Mobilization and establishment of a temporary camp for } \\
\text { storing/keeping equipment }\end{array}$ & Hours & 5 & 0.796 & 3.98 \\
\hline 2 & Pre-Curing & Hours & 3 & 0.796 & 2.388 \\
\hline 3 & Concrete (with formwork and all required activities) & Hours & 24 & 0.796 & 19.14 \\
\hline 4 & Hilti Hit-hy 200 adhesive for steel anchorage & Hours & 8 & 2 & 16 \\
\hline 5 & $\begin{array}{l}\text { Extra costs such as delays and security calculated for a } \\
\text { minimum of } 25 \mathrm{Km}\end{array}$ & Hours & 10 & 0.796 & 7.96 \\
\hline 6 & Demobilization and site cleaning & Hours & 5 & 0.796 & 3.98 \\
\hline 7 & Total Time Required (Hr) & 55 & & & \\
\hline 8 & Total (USD) & & & & 53.412 \\
\hline
\end{tabular}

\section{Results and Discussion}

This paper evaluated the feasibility of using the FRP-Wrapping method to strengthen columns based on strength, cost, time, and environmental concerns $\left(\mathrm{CO}_{2}\right.$ Emission) in Afghanistan. To better support the argument, the results were compared with RC jacketing, a common strengthening method in Afghanistan.

The results show that the FRP-Wrapping method can increase the control column's load-carrying capacity from $2283 \mathrm{kN}$ to $4176.25 \mathrm{kN}$ and the deteriorated column from $1356.05 \mathrm{kN}$ to $3082 \mathrm{kN}$. This shows $83 \%$ and $127 \%$ addition of strength in control and deteriorated columns where the final load-carrying capacities of these columns stand at $183 \%$ and $227 \%$, respectively. In contrast, RC jacketing displayed a higher efficiency and increased the control column's load-carrying capacity from $2283 \mathrm{kN}$ to $5177.66 \mathrm{kN}$ and for the deteriorated column from $1356.05 \mathrm{kN}$ to $4250.71 \mathrm{kN}$. This shows $126.8 \%$ and $213.5 \%$ addition of strength in control and deteriorated columns, where the final load-carrying capacity in these columns stand at $226.8 \%$ and $313.5 \%$ (Table 8) (Figures 5 and 6).

Table 8. Change in load-carrying capacity of both Control and Deteriorated Column after RC-Jacketing and FRP-Wrapping

\begin{tabular}{llllll}
\hline \multirow{2}{*}{ Specimen } & $\begin{array}{l}\text { Ultimate load-carrying } \\
\text { capacity as is }\end{array}$ & RC-Jacketed & \multicolumn{3}{l}{ FRP Wrapped } \\
\cline { 3 - 6 } & \multirow{2}{*}{ Capacity Added } & Final Capacity & Capacity Added & Final Capacity \\
\hline \multirow{2}{*}{ Control Column } & $2283 \mathrm{kN}$ & $2894.66 \mathrm{kN}$ & $5177.66 \mathrm{kN}$ & $1893.25 \mathrm{kN}$ & $4176.25 \mathrm{kN}$ \\
Deteriorated & & $126.8 \%$ & $226.8 \%$ & $83 \%$ & $183 \%$ \\
Column & \multirow{2}{*}{$1356.05 \mathrm{kN}$} & $2894.66 \mathrm{kN}$ & $4250.71 \mathrm{kN}$ & $1725.95 \mathrm{kN}$ & $3082 \mathrm{kN}$ \\
\hline
\end{tabular}




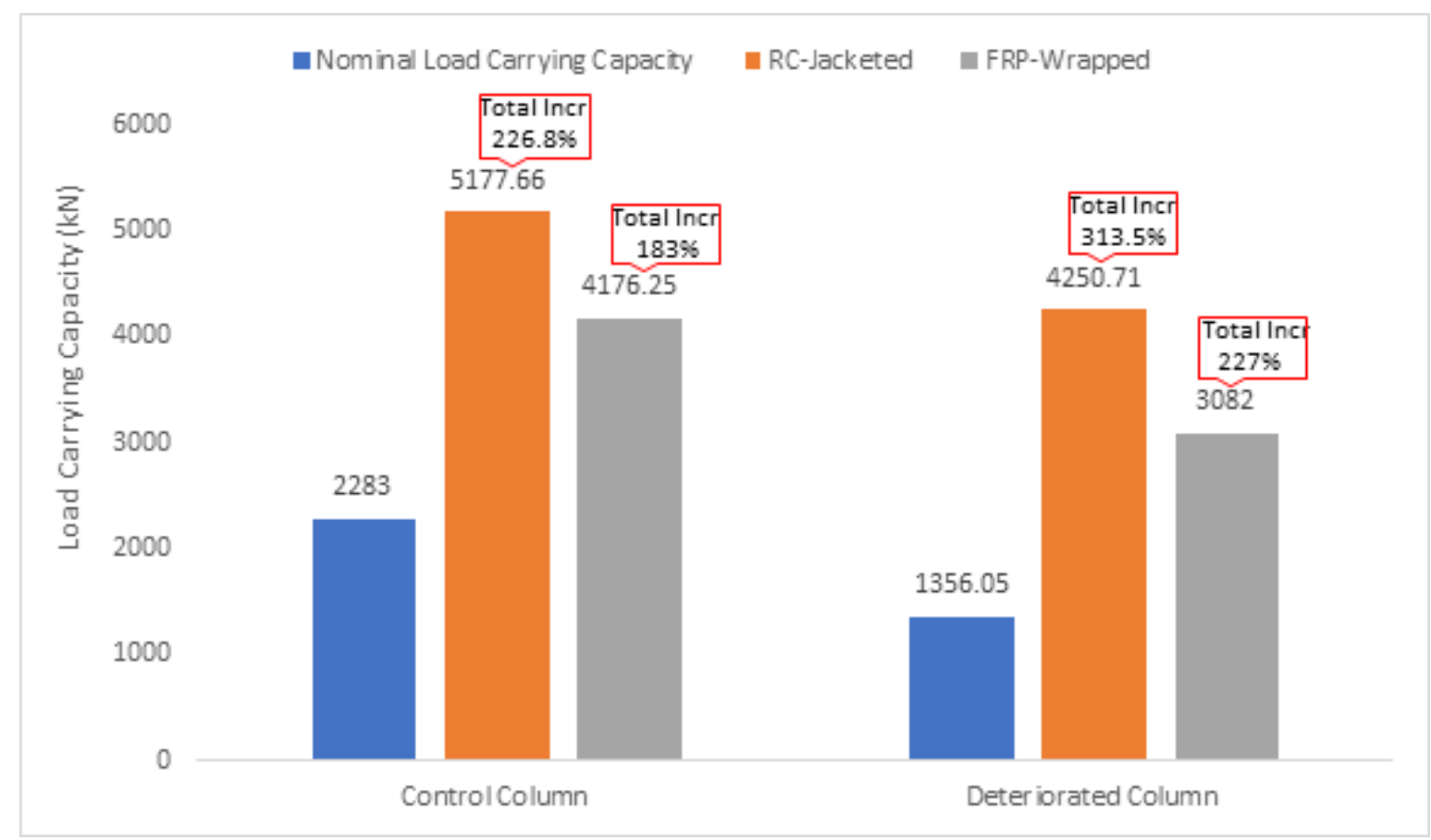

Fig 5. Increase in Total Load Carrying Capacity of Control Column and Deteriorated Column AfterRC-Jacketing and FRP-Wrapping

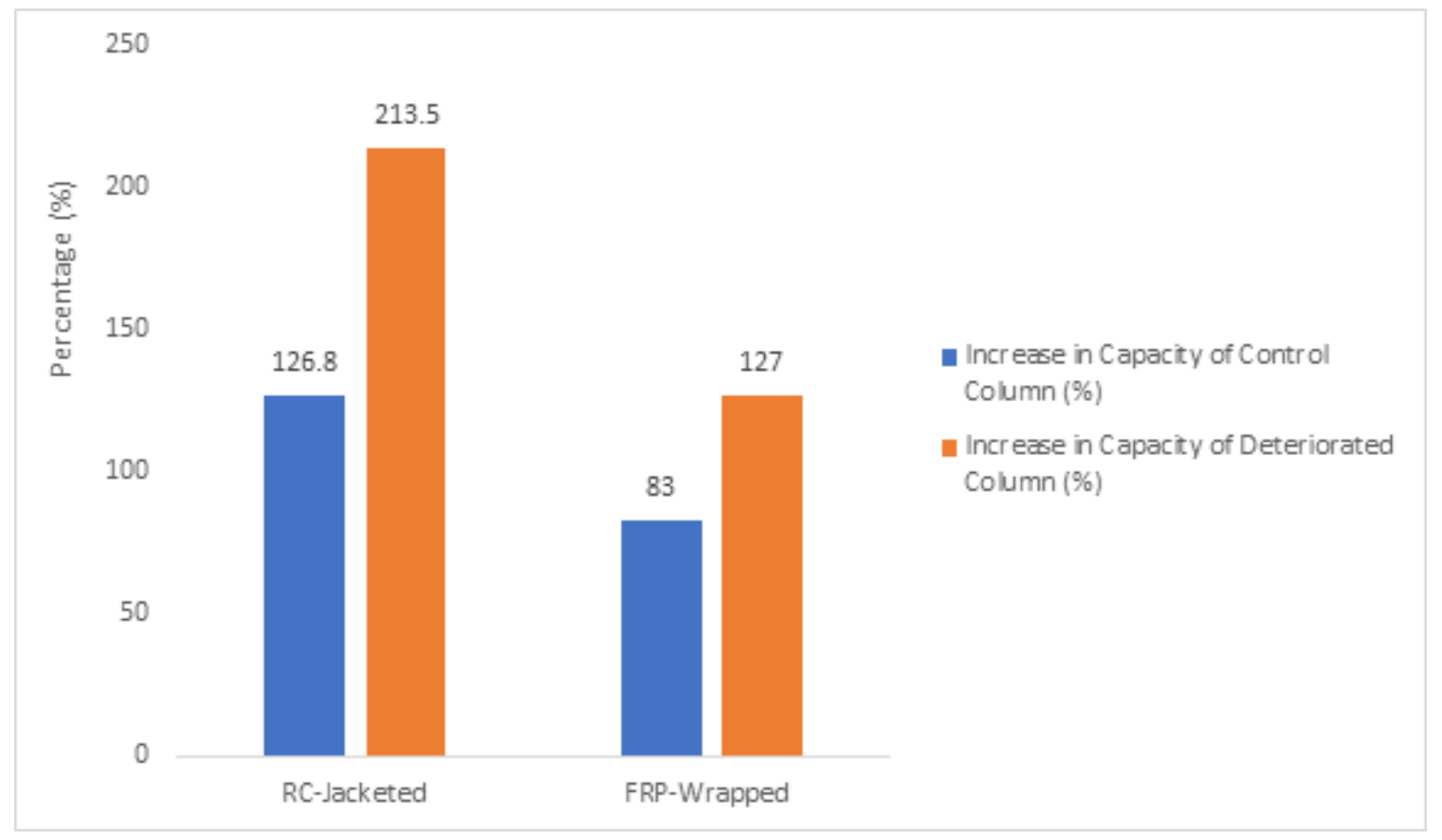

Fig 6. Net Increase in Load Carrying Capacity of Control Column and Deteriorated Column

The comparative cost analysis shows that the total cost for strengthening a concrete column by the FRP-wrapping method is around 2154.03 USD, while RC-Jacketing costs around 937.82 USD. Thus, as per the current market price in Afghanistan, the cost analysis reveals that the FRP-Wrapping method for strengthening the concrete column of structures is 2.3 times costlier than RC-jacketing (Figure 7). 


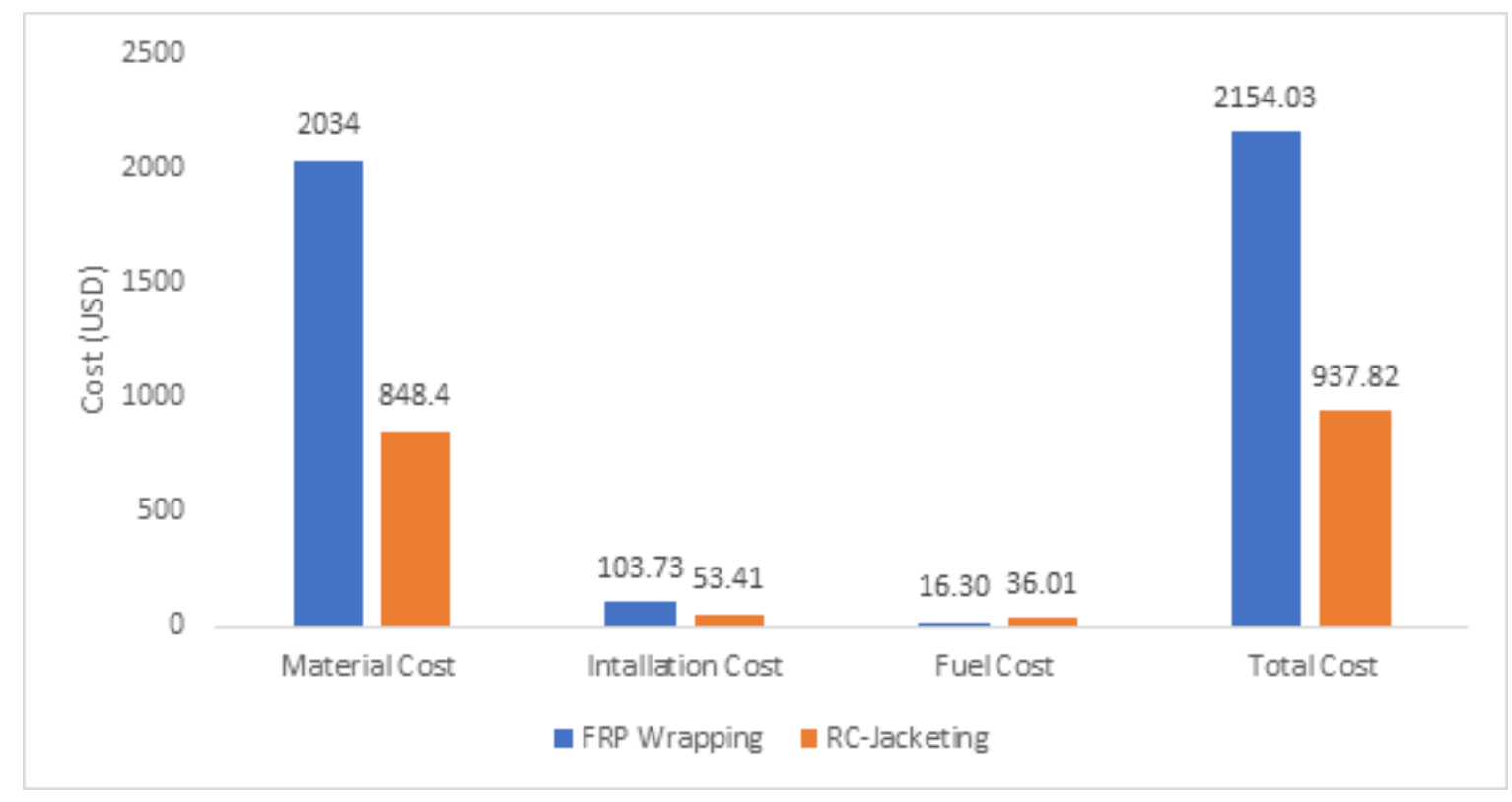

Fig 7. Cost analysis of FRP-wrapped and RC-Jacketed columns

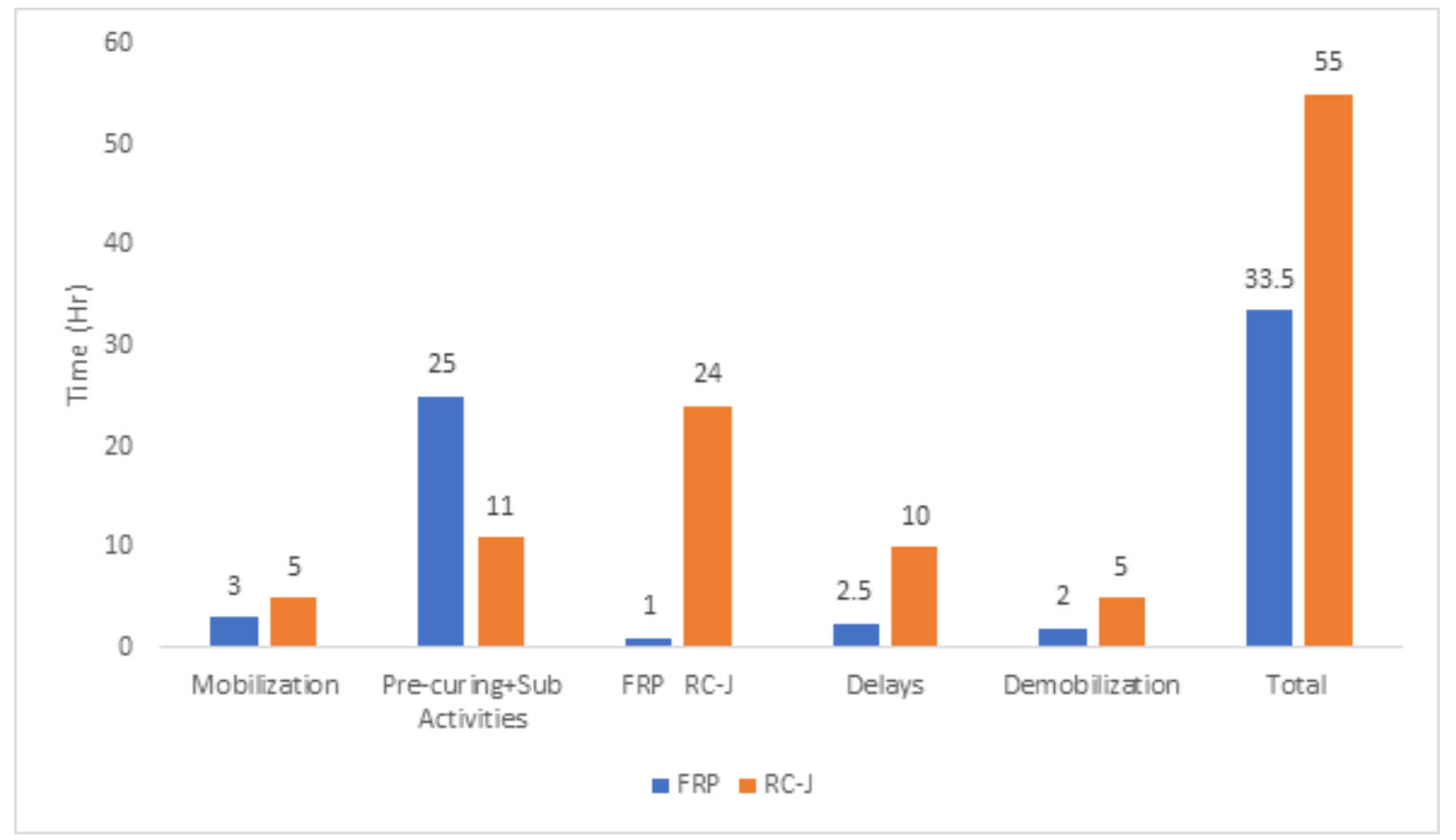

Fig 8. Time analysis of both FRP-wrapped and RC-jacketed columns procedure. 
Another parameter that this paper has focused on is the specification of structures in Kabul city, particularly the columns' geometry for which data was gathered through a survey. The results reveal that $90-95 \%$ of buildings in Kabul city have rectangular geometry, and only around $5-10 \%$ of the structures have columns with a circular cross-section, as mentioned in (Table 1). The geometry of the column is essential while selecting a strengthening method. In this case, comparing the confining pressure distribution between FRP-Wrapping and RC-Jacketing shows that the FRP-wrapping method is the more efficient while used for columns with circular cross-sections and has a lower slipping resistance if used for rectangular shaped columns (Figure 1).

While RC-Jacketing is much more efficient in terms of cost and strength than FRP wrapping, application time and $\mathrm{CO}_{2}$ emission are the factors where FRP-Wrapping is more competent. The total application time of FRP wrapping for strengthening a concrete column was calculated around 33.5 hours. In comparison, RC jacketing application time was roughly 55 hours, almost 21.5 hours behind FRP wrapping. Both these methods require a stable electricity supply, which Afghanistan lacks, and thus, portable electricity generators are needed, which again adds to the overall process's cost. Thus, the amount of $\mathrm{CO}_{2}$ emitted through burning fossil fuel was calculated and found around $62.1 \mathrm{Kg}$ and $137.126 \mathrm{Kg}$ for FRP-Wrapping and RC-Jacketing methods, respectively. The number of laborers required for the FRP-Wrapping method was also fewer than the RC-Jacketing method, around 4 and 7, respectively (Table 9). Furthermore, based on the study, this paper provided recommendations for using both FRP-Wrapping and RC-Jacketing methods appropriately, as the cost is a leading parameter for selecting the strengthening method in Afghanistan, yet there can be an exception for some structures.

Table 9. Additional facts regarding FRP-wrapping and RC-Jacketing.

\begin{tabular}{lll}
\hline Additional Findings & FRP & RC-Jacketing \\
\hline Total Fuel consumption (Liters) & 26.98 & 59.62 \\
Total CO2 Produced (Kg) & 62.1 & 137.126 \\
Total Number of Labor $\left(\mathrm{Ls}^{\star}\right)$ & 4 & 7 \\
\hline
\end{tabular}

$\mathrm{Ls}^{*}=$ Labor Scale

\subsection{Recommendations for efficiently using FRP-Wrapping method in Afghanistan}

Based on the results, the RC-jacketing method is much more cost-effective and easier to use than FRP-wrapping in Afghanistan. It is primarily because of raw material availability, better matching architecture, and prior usage experience; however, the FRPwrapping should also be used in some particular conditions. As FRP-wrapping usage is slowly growing to provide a better scope of its usage authors, have provided some recommendations on where to use this method for having higher efficiency. It is recommended to use FRP-wrapping in structures where overall maintenance time is limited and immediate recovery of strength is crucial such as bridges, other highway structures, or post-disaster structures. Furthermore, it should specifically be considered for maintenance of structure with historical value (monumental structures) because of restrictions for changing its cross-section (shape) or effective floor area. Moreover, this method should be used for overall weak structures, where their overall load-carrying capacity is already reduced significantly and using the RC-jacketing method will only add more load and instability. Additionally, FRP-wrapping should be considered to maintain structures where pollution of any kind (Noise or Air) is restricted, such as hospitals, kinder gardens/schools, and old age facilities). Finally, this method should consider strengthening the columns of high-rise structures if maintenance is required on higher floors because using the RC-jacketing method will change the initially designed seismic behavior of the structure.

\section{Conclusion}

This paper studied the feasibility of using the FRP wrapping method to strengthen concrete columns in Afghanistan. To better evaluate its feasibility as a strengthening method for concrete columns, it was compared with RC-jacketing based on strength, time, cost, and environmental impact parameters. The study conclusively shows that the RC-Jacketing method is more appropriate for strengthening the weak and partially deteriorated concrete columns in Afghanistan because of a higher strength per cost ratio. On the other hand, results reveal that the FRP-wrapping method is more time-efficient and has a lower carbon footprint. As this study focuses on strengthening concrete columns (compression members), a separate study should be conducted for flexural members. This study focused on concrete columns because it is common in Afghanistan; however, the same type of study is required for steel.

The main findings of this paper are shown below.

1. The overall maintenance process of FRP-wrapping was time-efficient comparing to RC jacketing. 
2. The carbon footprint through the FRP-Wrapping method was lower than that of RC-jacketing.

3. The RC-Jacketing method was able to add almost 50\% extra strength to columns than FRP-Wrapping.

4. RC-Jacketing method suits better with the current architecture of Afghanistan.

5. The overall cost of the maintenance process of FRP-Wrapping was $57 \%$ higher than RC-Jacketing.

6. RC jacketing method increased load-carrying capacity of the control column 1.5 times and load-carrying capacity of a deteriorated column around 1.7 times compared to FRP-Wrapping.

To conclude, for strengthening columns in Afghanistan, it is recommended to consider the RC-jacketing method, while for some exceptional cases mentioned in the recommendations section, FRP-wrapping can be considered as well.

\section{List of abbreviations}

$f c k=$ Concrete compressive/characteristic strength

$A c=$ Concrete area

$f y=$ Compressive yield strength of steel reinforcement

$A s c=$ Longitudinal reinforcement area

$\alpha p c=$ Circular column performance coefficient

ffrpu = Ultimate tensile strength of FRP

E frp $=$ Modulus of elasticity for FRP

$\mathrm{Nb}=$ Number of FRP layers

$f 1$ frp $=$ Ultimate confinement stress because of FRP reinforcement

tfrp $=$ FRP thickNess

$\omega w=$ ultimate confinement stress ratio FRP to RCC strength

$\varphi$ frp $=$ FRP resistance factor (1 for laboratory condition)

$\varepsilon f r p=$ FRP strain $(0.003)$

\section{References}

1) Malan LM. Sustainable construction in Afghanistan. Naval postgraduate school monterey CA. 2010. Available from: http://hdl.handle.net/10945/5191.

2) Malan LM. Sustainable construction in Afghanistan. Naval postgraduate school monterey CA. 2010. Available from: http://hdl.handle.net/10945/5191.

3) Aasim BA, Karimi AK, Tomiyama J, Aydan Ö. Numerical verification of accelerometer-based assessment of hollow-type pretensioned concrete girder. Asian Journal of Civil Engineering. 2020;21(3):437-447. Available from: https://dx.doi.org/10.1007/s42107-019-00219-w.

4) Karimi AK, Jaheed AB, Aasim BA, Farooqi JA. Structural Condition and Deficiencies of Present Constructed Bridges over Zahirshahi Canal and Proposal of New Design Using AASHTO Codes. World Journal of Engineering and Technology. 2019;07(02):325-332. Available from: https://dx.doi.org/10.4236/ wjet.2019.72023.

5) Karimi AK, et al. Experimental and numerical studies on the control of horizontal cracking at the ends of hollow-type pretensioned girders. SN Applied Sciences. 2020;2(10):1-17. Available from: https://doi.org/10.1007/s42452-020-03461-z.

6) Aasim B, et al. Detection of damage in concrete structure via shifts in natural frequency. Int J Tech Research Applica. 2017;5:48-52.

7) Karimi AK. Control of horizontal cracking at the ends of pretensioned hollow type BS12 PC-girder utilizing FEA. Int J Tech Res Appl. 2017;5(4).

8) Aasim BA, Karimi AK, Tomiyama J. Assessment of a Real-life Concrete Bridge Structure using Vibration-based Damage Detection Method. IOP Conference Series: Materials Science and Engineering. 2021;1054(1). Available from: https://dx.doi.org/10.1088/1757-899x/1054/1/012011.

9) Aydan Ö. A Comparative Study on Stress Distributions in Physical Models Using Photo-elasticity and FEM. In: International Conference of the International Association for Computer Methods and Advances in Geomechanics. Cham. Springer. 2021.

10) Ahmad AB, et al. Vibration-based comparison of accelerometer and microtremor sensors with numerical verification by assessing a PC-bridge. .

11) Nasiri A, Shimozato T, Mumtaz Y. Experimental study on the post-cracking behavior of preflex beams under cyclic loading. Structures. 2021;29:1390-1403. Available from: https://dx.doi.org/10.1016/j.istruc.2020.12.023.

12) Ahmadullah N, Tetsuhiro S, Tai M. A Study on Application of Elastic Theory for Computing Flexural Stresses in Preflex Beam. International Journal of Structural and Construction Engineering. 2017;11(10):1364-1367.

13) Toutanji H, Balaguru P. Durability Characteristics of Concrete Columns Wrapped with FRP Tow Sheets. Journal of Materials in Civil Engineering. 1998;10(1):52-57. Available from: https://dx.doi.org/10.1061/(asce)0899-1561(1998)10:1(52).

14) Hu J, Wang GC, Qian B, Mao ZQ. Inhomogeneous superconductivity induced by interstitial Fe deintercalation in oxidizing-agent-annealed and HNO3treated Fe1+y(Te1-xSex). Superconductor Science and Technology. 2012;25. Available from: https://dx.doi.org/10.1088/0953-2048/25/8/084011.

15) Pham TM, Doan LV, Hadi MNS. Strengthening square reinforced concrete columns by circularisation and FRP confinement. Construction and Building Materials. 2013;49:490-499. Available from: https://dx.doi.org/10.1016/j.conbuildmat.2013.08.082.

16) Wu G, Wu ZS, Lü ZT. Design-oriented stress-strain model for concrete prisms confined with FRP composites. Construction and Building Materials. 2007;21(5):1107-1121. Available from: https://doi.org/10.1016/j.conbuildmat.2005.12.014.

17) Raza S, et al. Strengthening and repair of reinforced concrete columns by jacketing: State-of-the-art review. Sustainability. 2019;11(11). Available from: https://doi.org/10.3390/su11113208.

18) Xiao Y, Ma R. Seismic Retrofit of RC Circular Columns Using Prefabricated Composite Jacketing. Journal of Structural Engineering. 1997;123(10):13571364. Available from: https://dx.doi.org/10.1061/(asce)0733-9445(1997)123:10(1357). 
19) Ma R, Xiao Y, Li KN. Full-scale testing of a parking structure column retrofitted with carbon fiber reinforced composites. Construction and Building Materials. 2000;14:63-71. Available from: https://dx.doi.org/10.1016/s0950-0618(00)00008-8.

20) Ye LP, Zhang K, Zhao SH, Feng P. Experimental study on seismic strengthening of RC columns with wrapped CFRP sheets. Construction and Building Materials. 2003;17(6-7):499-506. Available from: https://doi.org/10.1016/S0950-0618(03)00047-3.

21) Ye L, Yue Q, Zhao S, Li Q. Shear strength of reinforced concrete columns strengthened with carbon-fiber-reinforced plastic sheet. Journal of Structural Engineering. 1527;128(12). Available from: https://doi.org/10.1061/(ASCE)0733-9445(2002)128:12(1527).

22) Sause R, Harries KA, Walkup SL, Pessiki S, Ricles JM. Flexural behavior of concrete columns retrofitted with carbon fiber-reinforced polymer jackets. Structural Journal. 2004;101(5):708-716.

23) Ghobarah A, Galal KE. SEISMIC REHABILITATION OF SHORT RECTANGULAR RC COLUMNS. Journal of Earthquake Engineering. 2004;8(1):45-68. Available from: https://dx.doi.org/10.1080/13632460409350480.

24) Haroun MA, Elsanadedy HM. Fiber-Reinforced Plastic Jackets for Ductility Enhancement of Reinforced Concrete Bridge Columns with Poor Lap-Splice Detailing. Journal of Bridge Engineering. 2005;10(6):749-757. Available from: https://dx.doi.org/10.1061/(asce)1084-0702(2005)10:6(749).

25) Buyukozturk O, Yu TY. A Novel Structural Assessment Technique to Prevent Damaged FRP-Wrapped Concrete Bridge Piers from Collapse. In: Seismic Risk Assessment and Retrofitting . Dordrecht. Springer. 2009;p. 127-141. Available from: https://doi.org/10.1007/978-90-481-2681-1_7.

26) Liu J, Sheikh SA. Fibre-reinforced polymer-confined circular columns under simulated seismic loads. Aci Struct J. 2013;110:941-951.

27) Haroun MA, Elsanadedy HM. Fiber-Reinforced Plastic Jackets for Ductility Enhancement of Reinforced Concrete Bridge Columns with Poor Lap-Splice Detailing. Journal of Bridge Engineering. 2005;10(6):749-757. Available from: https://dx.doi.org/10.1061/(asce)1084-0702(2005)10:6(749).

28) Larachi F, Munteanu MC. Magnetic emulation of microgravity for earth-bound multiphase catalytic reactor studies-Potentialities and limitations. AIChE Journal. 2009;55:1200-1216. Available from: https://dx.doi.org/10.1002/aic.11752.

29) Habib A, Yildirim U, Eren O. Column repair and strengthening using RC jacketing: a brief state-of-the-art review. Innovative Infrastructure Solutions. 2020;5(3):1-11. Available from: https://dx.doi.org/10.1007/s41062-020-00329-4.

30) Tayeh BA, Naja MA, Shihada S, Arafa M. Repairing and Strengthening of Damaged RC Columns Using Thin Concrete Jacketing. Advances in Civil Engineering. 2019;2019:1-16. Available from: https://dx.doi.org/10.1155/2019/2987412.

31) Aguilar J, Juárez H, Ortega R, Iglesias J. The Mexico Earthquake of September 19, 1985-Statistics of Damage and of Retrofitting Techniques in Reinforced Concrete Buildings Affected by the 1985 Earthquake. Earthquake Spectra. 1989;5:145-151. Available from: https://dx.doi.org/10.1193/1.1585516.

32) Chang SY, Chen TW, Tran NC, Liao WI. Seismic retroftting of RC columns with RC jackets and wing walls with different structural details. Earthquake Engineering and Engineering Vibration. 2014;13(2):279-292. Available from: https://doi.org/10.1007/s11803-014-0230-4.

33) Alcocer S, Jirsa JO. Assessment of the response of reinforced concrete frame connections redesigned by Jacketing. InProceedings of the Fourth US National Conference on Earthquake Engineering. 1990;3:295-304.

34) Rodriguez M, Park R. Seismic load tests on reinforced concrete columns strengthened by jacketing. Structural Journal. 1994;91(2):150-159.

35) Stoppenhagen DR, Jirs JO, Wyllie LA. Seismic repair and strengthening of a severely damaged concrete frame. Structural Journal. $1995 ; 92$ (2):177-187.

36) Vandoros KG, Dritsos SE. Concrete jacket construction detail effectiveness when strengthening RC columns. Construction and Building Materials. 2008;22:264-276. Available from: https://dx.doi.org/10.1016/j.conbuildmat.2006.08.019.

37) Lehman DE, Gookin SE, Nacamuli AM, Moehle JP. Repair of earthquake-damaged bridge columns. Structural Journal. 2001;98(2):233-242.

38) Marlapalle VC, Salunke PJ, Gore NG. Analysis \& design of RCC jacketing for buildings. International Journal of Recent Technology and Engineering. 2014;3(3):62-63. Available from: https://doi=10.1.1.677.7181\&rep=rep1\&type=pdf. 